\title{
BORON IN PREVENTING OF SHOOT DIEBACK ON EUCALYPTUS BENTHAMII GROWN IN SOIL WITH DIFFERENT WATER REGIMES
}

\author{
Boro na prevenção da seca-de-ponteiros de Eucalyptus benthamii cultivado em solo com diferentes regimes hidricos
}

\author{
Luciana Patrícia Rosa Dias ${ }^{1 *}$; Luciano Colpo Gatiboni²; David José Miquelutti²; Gustavo Brunetto ${ }^{3}$; Diego Joaquim \\ Pereira Campos ${ }^{4}$
}

\begin{abstract}
${ }^{1}$ Doutora em Ciência do Solo; Engenheira Agrônoma; Professora do Instituto Federal Catarinense (IFC - Campus Rio do Sul); Área Agrária; Professora da FAMESUL/UNIASSELVI - Área: Engenharia Civil; E-mail: lupatidias@hotmail.com (*AUTOR PARA CORRESPONDÊNCIA)

${ }^{2}$ Professores do Departamento de Solos e Recursos Naturais da Universidade do Estado de Santa Catarina - UDESC; e-mail: lgatiboni@gmail.com e david.miquelluti@udesc.br.

${ }_{3}^{3}$ Professor do Departamento de Solos, Universidade Federal de Santa Maria - UFSM; E-mail: brunetto.gustavo@gmail.com

${ }^{4}$ Engenheiro Florestal - Universidade do Estado de Santa Catarina - UDESC; E-mail: dipcampos@yahoo.com.br
\end{abstract}

Artigo enviado em 31/05/2017, aceito em 05/07/2017 e publicado em 29/09/2017.

\begin{abstract}
Abstrat: The water deficit interferes in the boron (B) uptake by eucalyptus, causing shoot dieback in young plants. The objective of this study was to evaluate the occurrence of shoot dieback in Eucalyptus benthamii submitted to doses of boron and water regimes in a Humic Cambisol of the Southern Plateau of the state of Santa Catarina. The experiment was conducted in greenhouse (Lages-SC) in a completely randomized experimental design, in a $4 \mathrm{x} 3$ factorial scheme, with three replications, adding $0,0.55,1.1$ and $2.75 \mathrm{~g}$ boron plant $^{-1}$ in the soil, and three water regimes (60, 80 and 100\% of the field capacity). The stem diameter and the plants height were measured, using a visual analysis of dieback. The dry mass and boron contents in the tissues and in the soil, were also determined. Water deficiency affected negatively dry matter but it was not affected by boron application. The highest occurrence of shoot dieback was observed in the treatments without addition of boron and in the more restrictive water regime. Fertilization with $0.55 \mathrm{~g}$ boron plant $^{-1}$ in soil was sufficient to avoid shoot dieback.
\end{abstract}

Key words: eucalyptus, borax, water availability, micronutrient

Resumo: O déficit hídrico interfere na absorção de boro (B) pelo eucalipto, causando a seca-de-ponteiros nas plantas jovens. Objetivou-se avaliar a ocorrência de seca-de-ponteiros em Eucalyptus benthamii submetido às doses de boro e regimes hídricos em Cambissolo Húmico do Planalto Sul Catarinense. O experimento foi conduzido em casade-vegetação (Lages-SC) em delineamento experimental inteiramente casualizado, em esquema fatorial $4 \times 3$, com três repetições, com adição de 0, 0,55, 1,1 e 2,75 g boro planta ${ }^{-1}$ no solo, e três regimes hídricos $(60,80$ e $100 \%$ da capacidade de campo). Foi mensurado o diâmetro do coleto e altura das plantas, realizada a análise visual de seca-deponteiros, determinada a massa seca e teores de boro nos tecidos e no solo. A deficiência hídrica afetou negativamente o crescimento das plantas e não houve resposta em massa seca das plantas à aplicação de boro. A maior ocorrência de seca-de-ponteiros foi observada nos tratamentos sem adição de boro e no regime hídrico mais restritivo. A aplicação de $0,55 \mathrm{~g}$ boro planta $^{-1}$ no solo foi suficiente para evitar a seca-de-ponteiros.

Palavras chave: eucalipto, bórax, disponibilidade de água, micronutriente 


\section{INTRODUCTION}

In Brazil, the implantation of planted forests began more than a century ago. Currently, there are more than 7.4 million ha forested with eucalyptus, and approximately 308 thousand ha are located in the state of Santa Catarina, according to information from the Brazilian Institute of Geography and Statistics (IBGE, 2015), which conditions the high economic importance of this genus as well as the studies to improve its nutrition and relative increase in productivity.

The importance of boron (B) is associated with the formation of the cell wall, more specifically in the synthesis of its components, such as pectin, cellulose and lignin (SILVEIRA et al., 2002; TAIZ; ZEIGER, 2013).

The symptoms of boron deficiency in eucalyptus are characterized by deformations of growth shoots; small, deformed and chlorotic new leaves; shortening of internodes and, in severe situations, it causes dieback and death, with loss of dominant growth and regrowth of lateral buds (VAIL; CALTON; STRANG, 1957; SILVEIRA et al., 2002; LEITE; MARINO; BONINE, 2010), especially during dry seasons.

For eucalyptus, dieback occurs in the first year of cultivation, affecting the growth and development of the plants until the third year. If, in this period, the B deficiency is not very serious the plant can recover (MATIELLO et al., 2009).

Organic matter is considered the main source of $B$ because almost all of the nutrient absorbed by the plants originates from its mineralization, a process that is reduced during the drought, due to a low activity of the microbial population. In addition, the drought causes a lower transport of $\mathrm{B}$ by mass flow to the surface of the roots, causing an increase in the nutrient demand by eucalyptus (MALAVOLTA \& KLIEMANN, 1985; MATIELLO et al., 2009; TIRLONI et al., 2011; SCHWIDER et al., 2013).

Water has a direct influence on the initial development of eucalyptus, and its lack causes a significant reduction of biomass (STAPE et al., 2010; SCHWIDER, 2013; KLIPPEL et al., 2014) delimiting plant growth.

The soils of the Southern Plateau of Santa Catarina, cultivated with eucalyptus, have high levels of organic matter, conferring them hypothetically good availability of $\mathrm{B}$, dispensing borated fertilization. However, the possible occurrence of water deficit in the region may decrease the availability of $\mathrm{B}$ to eucalyptus, mainly in early summer (the period of greatest annual growth and nutrient demand, considering that the planting goes from October to February in the region), becoming insufficient to supply their need.

This study aimed to evaluate the occurrence of shoot dieback in Eucalyptus benthamii submitted to doses of B and water regimes, in soil with high organic matter content of the Southern Plateau of Santa Catarina.

\section{MATERIALS AND METHODS}

The study was conducted in a greenhouse at the Department of Soils of the University of the State of Santa Catarina (UDESC), in Lages (SC), using seminal seedlings of Eucalyptus benthamii Maiden et Cambage, from October 2013 to February 2014.

Samples of a Cambissolo Húmico alumínico léptico (EMBRAPA, 2013), Humic Cambissol in WRB/FAO soil classification, were collected in the $0.00-0.20 \mathrm{~m}$ layer in a native pasture, which was used after being air dried and sieved with a 4-mm mesh.

The soil had $250 \mathrm{~g} \mathrm{~kg}^{-1}$ of clay; $48 \mathrm{~g} \mathrm{~kg}^{-1}$ of organic matter; $\mathrm{pH}$ in water of $4.4(1: 1)$; $\mathrm{H}+\mathrm{Al}$ of 19.4 cmolc kg-1 ; SMP Index 4.7; $3.2 \mathrm{cmol}_{\mathrm{c}} \mathrm{dm}^{-3}$ of $\mathrm{Ca}^{2+} ; 1.4$ $\mathrm{cmol}_{\mathrm{c}} \mathrm{dm}^{-3}$ of $\mathrm{Mg}^{2+} ; 4.8 \mathrm{cmol}_{\mathrm{c}} \mathrm{dm}^{-3}$ of $\mathrm{Al}^{3+} ; 14.8 \mathrm{mg}$ $\mathrm{dm}^{-3}$ of available $\mathrm{P}$ (Mehlich-1); $121 \mathrm{mg} \mathrm{dm}^{-3}$ of available $\mathrm{K}$ (Mehlich-1); $0.2 \mathrm{mg} \mathrm{dm}^{-3}$ of available B; 8.9 $\mathrm{cmol}_{\mathrm{c}} \mathrm{dm}^{-3}$ of effective CTC; $24.3 \mathrm{cmol}_{\mathrm{c}} \mathrm{dm}^{-3}$ of CTC at $\mathrm{pH} 7.0 ; 20.2 \%$ of saturation per base and $53.9 \%$ of saturation per Al (TEDESCO et al., 1995).

For the cultivation, the soil was stored in pots with a capacity of $3 \mathrm{~kg}$ where correctives and fertilizers were applied according to CQFS-RS / SC (2004), using the equivalent of $4.0 \mathrm{t} \mathrm{ha}^{-1}$ of limestone filler (dose to raise the ${ }_{\mathrm{pH}}$ (in water up to 5.5), $\mathrm{N}\left(45 \mathrm{~kg} \mathrm{ha}^{-1} \mathrm{~N}\right.$ in the form of urea), $\mathrm{P}\left(30 \mathrm{~kg} \mathrm{ha}^{-1}\right.$ of $\mathrm{P}_{2} \mathrm{O}_{5}$ in the form of SFT) and $\mathrm{K}\left(20 \mathrm{~kg} \mathrm{ha}^{-1}\right.$ de $\mathrm{K}_{2} \mathrm{O}$ in the form of $\left.\mathrm{KCl}\right)$, considering the existence of 2,000 $\mathrm{t}$ of soil per hectare.

The experimental design used was completely randomized, in a $4 \times 3$ factorial arrangement, with three replications. The doses of $\mathrm{B}$ were calculated according to the recommendation of micronutrients for the cultivation of eucalyptus in the State of Minas Gerais $\left(10 \mathrm{~g} \mathrm{plant}^{-1}\right.$ of Borax or $\left.1.1 \mathrm{~g} \mathrm{~B} \mathrm{plant}^{-1}\right)$, in a spacing $2.5 \times 2.5 \mathrm{~m}$ (1,600 plants ha-1).

The treatments were: $0,0.55,1.10$ and $2.75 \mathrm{~g}$ B plant ${ }^{-1}$, using Borax as source, which was diluted in water and applied directly to the soil surface in the pots.

In order to obtain the water regimes, the gravimetric soil moisture $\left(224 \mathrm{~g} \mathrm{~kg}^{-1}\right)$ was determined and the three water regimes used to conduct the 
experiment were determined (60, 80 and 100\% field capacity - FC).

Before the application of the $\mathrm{B}$ doses, all pots were adjusted to $100 \%$ of the $\mathrm{FC}$, and later the period of adjustment of the water regimes was initiated, where the pots were weighed daily and irrigated differently until reaching the corresponding water regime, when the addition of boron doses and the planting of eucalyptus seedlings (one per pot) were carried out.

Weighing and correction of pot moisture occurred daily throughout the experimental period. $\mathrm{N}$ was applied weekly (diluted in water and applied to the soil in the pot) in coverage, in the total dose equivalent to $45 \mathrm{~kg} \mathrm{ha}^{-1}$. The plants were cultivated for 110 days and data on stem diameter $(\mathrm{mm})$ were collected weekly, using a digital caliper and those of the height $(\mathrm{cm})$ of the plants with a graduated ruler.

The visual analysis of the plants for the detection of damage caused by dieback was carried out at 110 days after the treatments application through scores attributed by nine evaluators, based on a template constructed in loco, where for the most affected plant of the experiment a score 5 was attributed and for the plant with no visible symptoms was attributed score 1; for the plant that represented an intermediate damage was attributed score 3.

The template is shown in Figure 1 and it was estimated that the percentages of damage were: score $1=$ no visual damage; score $2=5 \%$ damage; score $3=$ $10 \%$ damage; score $4=15 \%$ damage and score $5=$ $20 \%$ damage.

At the time of harvest, the plants were cut at the neck and then separated into leaves, stem/branches and roots. The parts were oven dried with forced air circulation at $65^{\circ} \mathrm{C}$.

For the extraction of B from the plant tissues, dry digestion in a muffle furnace was carried out for 2 $\mathrm{h}$ at $550{ }^{\circ} \mathrm{C}$, and the determination of the $\mathrm{B}$ content was done through the azomethine-H colorimetric method (EMBRAPA, 1999).

In the soil after harvest the available B was determined according to Tedesco et al. (1995).

The data of dry mass production of the plants and of $\mathrm{B}$ contents in plant tissue and in soil were submitted to analysis of variance and when significant effects of the treatments were detected, regression equations were adjusted using the software SISVAR 5.3 (FERREIRA, 2011). For the visual diagnosis of shoot dieback, the results were submitted to analysis of variance and to the Tukey test at $5 \%$ probability of error.

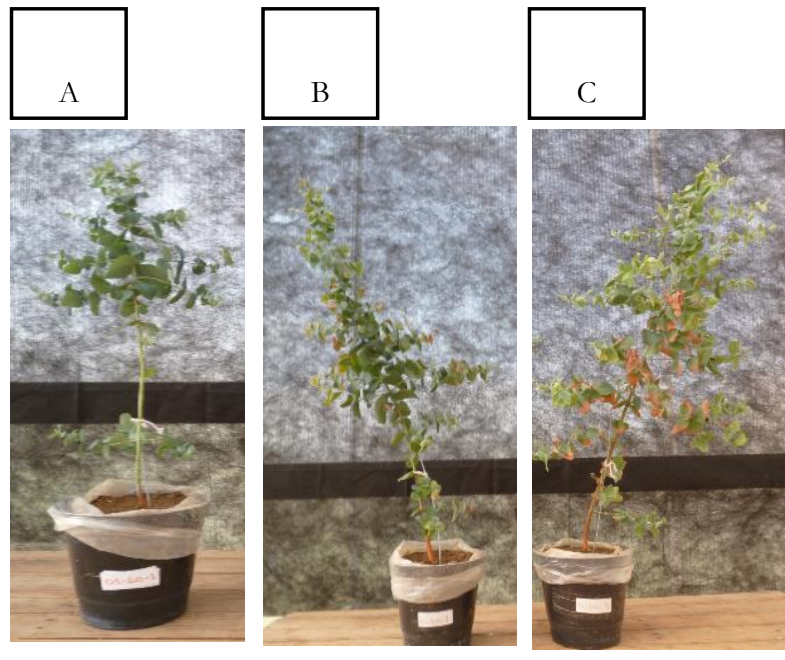

Figure 1. Template for the attribution of scores of the visual analysis of Eucalyptus benthamii submitted to boron doses and water regimes: A) - plants with no visible damage (score 1); B) - plants with $10 \%$ of damages (score 3) and C) - plants with $20 \%$ of damages (score 5)

\section{RESULTS AND DISCUSSION}

In the analysis of variance for leaf dry matter (DLM), dry mass of stem/branches (DMSB), dry mass of root (RDM), shoot dry mass (DMAP) and total dry mass (TDM), a response was detected only for water regimes, with no effect of $\mathrm{B}$ doses and no interaction between water regimes and $\mathrm{B}$ doses (Figures $2 \mathrm{~A}$ and 2B).

For DLM, DMSB and RDM the increase in the water regime from 60 to $100 \%$ increased the dry mass yield 2.6, 2.8 and 1.8 times, respectively (Figure 2A).

A similar result was obtained for the DMAP and TDM, with a 2.7 and 2.3-fold increase of the water regime from 60 to $100 \%$ (Figure $2 \mathrm{~b}$ ).

At the moment of the separation of the roots from the soil for the determination of the RDM, it was observed that there was no tangling of roots in any of the treatments with $\mathrm{B}$, evidencing that the use of the pots with capacity for $3 \mathrm{~kg}$ of soil was sufficient and suitable for the conduction of this study.

There was an increase of $33 \%$ in the stem diameter and $56 \%$ in the height of the plants with the increase in the water regime from 60 to $100 \%$ of the FC. 

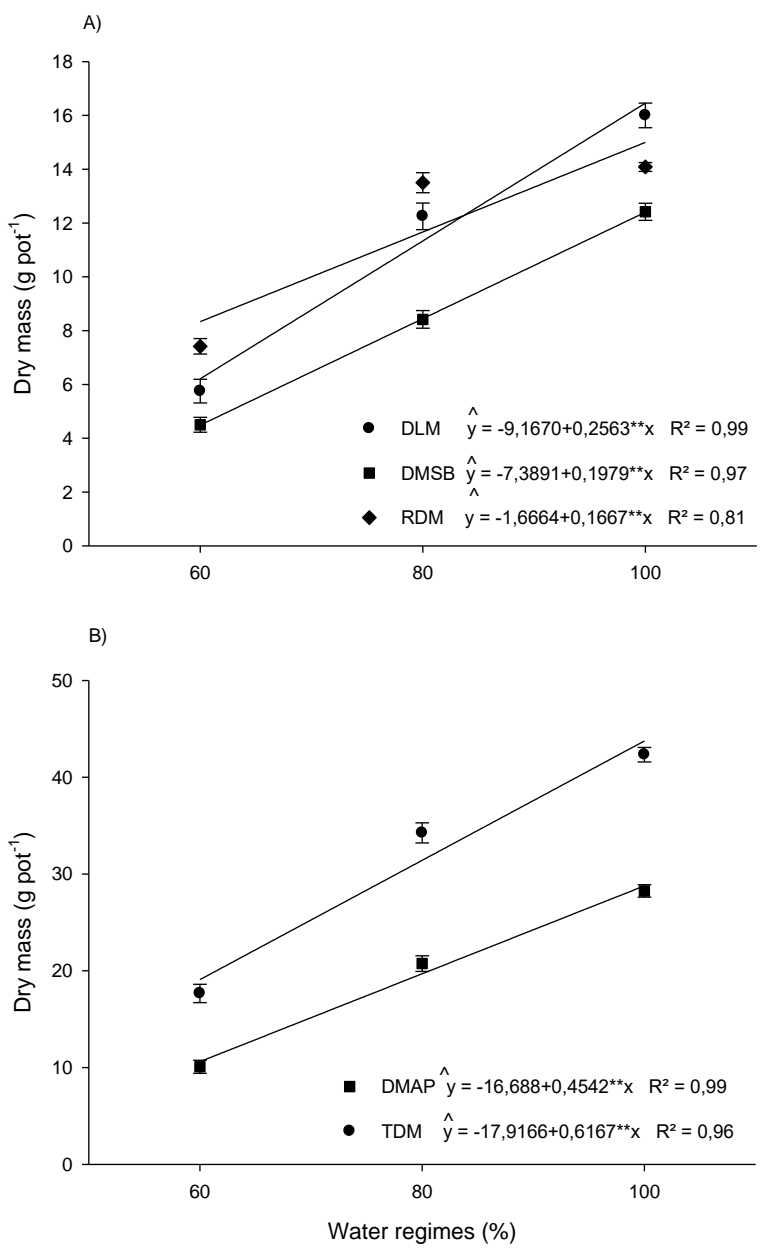

Figure 2. A) Dry leaf mass (DLM), dry mass of stem and branches (DMSB), root dry mass (RDM); B) dry mass of aerial part (DMAP) and total dry mass (TDM) of Eucalyptus benthamii submitted to the doses of boron and to the water regimes. (** = significant $P$-value at $1 \%$ by the F-test)

For the production of dry mass, the main response factor in eucalyptus production was the availability of water offered by the different hydric regimes; in the soil maintained with $60 \%$ of the FC it produced 2.7 times less DMAP than the soil with $100 \%$ of the FC. For roots, the reduction was 1.8 times for the same treatments.

Similarly, the height and diameter of the Eucalyptus benthamii stem showed a significant response only to the different water regimes, with no effect of B doses and no interaction between water regimes and B doses (Figure 3).

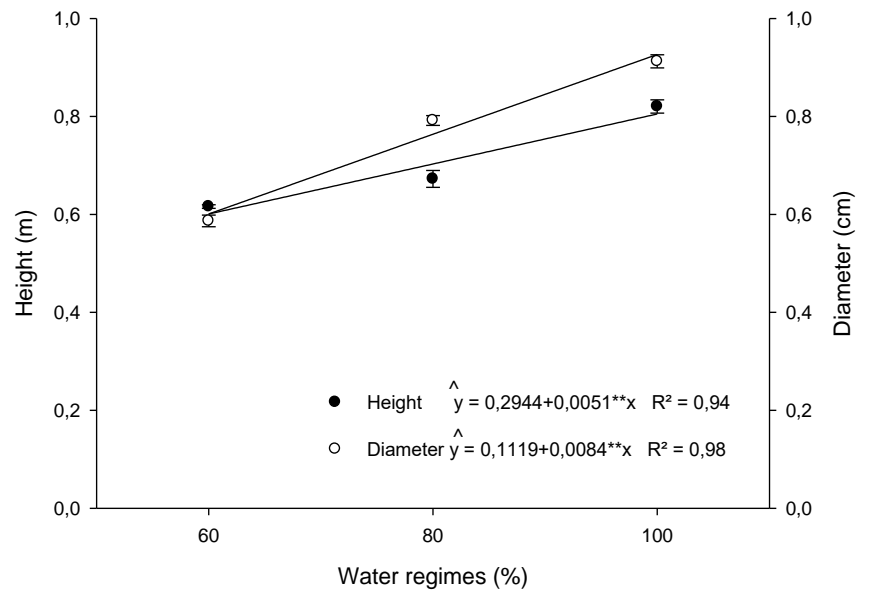

Figure 3. Height and diameter of the stem of Eucalyptus benthamii submitted to boron doses and to water regimes. (** = significant $\mathrm{P}$-value at $1 \%$ by the $\mathrm{F}$-test)

This happened probably because with the decrease of water in the soil the plant underwent a series of physiological and metabolic changes, resulting in the immediate reduction of biomass production and of the initial growth, which limited the growth of branches, stem, number of leaves and of the leaf area (SCHWIDER et al., 2013), proving that water deficiency is the main environmental factor that directly affects forest productivity (MATIELLO et al., 2009; STAPE et al., 2010; SCHWIDER et al., 2013).

The application of $\mathrm{B}$ to the soil, regardless of the dose, did not increase stem diameter, plant height or dry mass in all portions of the plant, indicating that $\mathrm{B}$ would not be a limiting nutrient in this soil.

This can happen because air and soil temperatures during most of the months of the year are low (Cfb climate), which favors the maintenance of high levels of organic matter in the soil, which, when mineralized, gradually over time can increase the availability of $\mathrm{B}$ to the plants. In addition, the $\mathrm{B}$ content in the soil without the addition of $\mathrm{B}$ was 0.2 $\mathrm{mg} \mathrm{dm}{ }^{-3}$, interpreted as median $\left(0.1-0.3 \mathrm{mg} \mathrm{dm}^{3}\right)$ by the Soil Chemistry and Fertility Commission (RS/SC) (CQFS-RS/SC, 2004).

A similar result was observed by Celestrino et al. (2015) in Eucalyptus urophylla, which 24 months after planting presented an increase in B concentration in the leaves in response to foliar application, however, there was no improvement in growth, diameter or volume of wood.

Working with Corymba citriodora in Mato Grosso do Sul, Tirloni et al. (2011) reported that B 
applications both at the beginning of the dry season and in the rainy season did not influence the height and diameter of the plants until 29 months of age.

The analysis of variance of the scores from the visual analysis of plant dieback showed a significant effect of $\mathrm{B}$ doses and the water regimes, but there was no interaction between $\mathrm{B}$ doses and water regimes. The highest mean score (4.3) occurred in the treatment without application of $\mathrm{B}$ and with greater water restriction (Table 1).

Approximately 60 days after fertilization with $\mathrm{B}$, the occurrence of foliar damages was observed, mainly in plants without addition of the nutrient, regardless of the water regime. The average score of the plants was 3.2, being higher than the one attributed to the plants with the other doses of $\mathrm{B}$, which did not differ between themselves. In the different water regimes, plants submitted to $60 \%$ of FC presented more visual symptoms than those with $80 \%$ of FC.

Characteristic symptoms of B deficiency, such as tissue necrosis, shoot dieback and overgrowth of lateral buds (SGARBI et al., 1999) were observed during the conduction of the study and lasted up to 110 days, when the visual analysis and the harvest of the plants was carried out. The visual analysis of damages showed that between 15 and $20 \%$ of the leaf area of the plants were necrotic in the treatment without $\mathrm{B}$ and with greater water restriction.

In general, the effect was clearer for the B factor than for the water regime factor and, on average, the plants without B application presented, regardless of the water regime, between 10 and $15 \%$ of visible damages.

The application of $\mathrm{B}$ at a dose equivalent to $0.55 \mathrm{~g} \mathrm{plant}^{-1}$ proved to be efficient in drastically reducing the occurrence of dieback, regardless of the water regime. This represents half of the dose indicated in the recommendation for eucalyptus production in Minas Gerais (NOVAIS et al., 2007) and it is an indication that the dose of $\mathrm{B}$ in subtropical soils with high levels of organic matter may be reduced, but not suppressed.

The $\mathrm{B}$ levels in leaves (BCL) and stem/branches (BSB) increased with B doses, with no statistical significance for water regimes and no interaction between $\mathrm{B}$ doses and water regimes (Figure $4 \mathrm{~A}$ ), indicating that in the present case the water deficiencies in the intensity tested did not cause a significant reduction of the absorption of $\mathrm{B}$. As for the $\mathrm{B}$ content in the roots (BR), there was no significance for the sources of variation.
Table 1. Overall mean visual evaluation of damage in Eucalyptus benthamii submitted to boron doses and to water regimes under greenhouse conditions at $\mathbf{1 1 0}$ days of conduction

\begin{tabular}{ccccc}
\hline $\begin{array}{c}\text { Doses B } \\
\left.\text { g plant }^{-1}\right)\end{array}$ & \multicolumn{3}{c}{ Water regime $(\%)$} & Average \\
\cline { 2 - 4 } & 60 & 80 & 100 & \\
\hline 0 & 4.3 & 2.3 & 3.1 & $3.23 \mathrm{a}^{(1)}$ \\
0.5 & 1.9 & 1.1 & 1.5 & $1.50 \mathrm{~b}$ \\
1 & 1.9 & 1.4 & 2.2 & $1.83 \mathrm{~b}$ \\
2.5 & 1.7 & 1.4 & 2.2 & $1.77 \mathrm{~b}$ \\
Average & $2.45 \mathrm{a}$ & $1.55 \mathrm{~b}$ & $2.25 \mathrm{ab}$ & \\
\hline
\end{tabular}

(1) Averages followed by equal letters in the row or column, do not differ by Tukey test $(\mathrm{P}<0.05)$. $\mathrm{CV}=34.7 \%$.

The contents of B in leaf tissue are interpreted as suitable for Eucalyptus grandis $\mathrm{x}$ Eucalyptus urophylla between 13 and $30 \mathrm{mg} \mathrm{kg}^{-1}$, and between 8 and $12 \mathrm{mg}$ $\mathrm{kg}^{-1}$ as deficient (MALAVOLTA et al., 1997). Are also considered adequate levels of B for Eucalyptus spp. the values between 30 and $50 \mathrm{mg} \mathrm{kg}^{-1}$ (CQFS-RS/SC, 2004).

In the present study, the leaf contents were 5 $\mathrm{mg} \mathrm{kg}-1$ in the soil without application of $\mathrm{B}$, increasing to just over $30 \mathrm{mg} \mathrm{kg}^{-1}$ in the soil with application of $0.55 \mathrm{~g}$ plant $^{-1}$ of $\mathrm{B}$. This indicates that the value of 30 $\mathrm{mg} \mathrm{kg}{ }^{-1}$ could be an appropriate reference value for Eucalyptus benthamii.

However, it should be considered that these are young plants in a greenhouse environment, and that the foliar contents of B may vary depending on the genetic material, the growing environment and the age of the plants. Also, water stress decreases the absorption and distribution of B in the plant, increasing the external nutrient requirement (DELL \& HUANG, 1997). The leaf content of $B$ in the eucalyptus plants varied according to the water regime (MATIELLO et al., 2009), which was not observed in the conduction of this study.

The $\mathrm{B}$ contents in the soil increased significantly with the B levels (Figure 4B), suffering no influence of water regimes and there were no interactions between $\mathrm{B}$ doses and water regimes (from 0.2 to $0.8 \mathrm{mg} \mathrm{dm}^{-3}$, with the highest dose of $\mathrm{B}(2.75 \mathrm{~g} \mathrm{~B}$ plant $\left.^{-1}\right)$ ).

There was an increase in soil B contents of $0.24 \mathrm{mg} \mathrm{dm}^{-3}$ in the control to $0.34 \mathrm{mg} \mathrm{dm}^{-3}$ in the soil with application of $0.55 \mathrm{~g} \mathrm{~B}$ plant $^{-1}$, indicating that the critical soil level of $0.30 \mathrm{mg} \mathrm{dm}^{-3}$ recommended by the Soil Chemistry and Soil Fertility Commission (RS / SC) (CQFS-RS / SC, 2004) is adequate for the soils of the region and sufficient to raise soil contents to the appropriate level.

Thus, although the soils of the region have high levels of organic matter, as a safety prescription it 
would be recommended to apply this dose when planting eucalyptus.
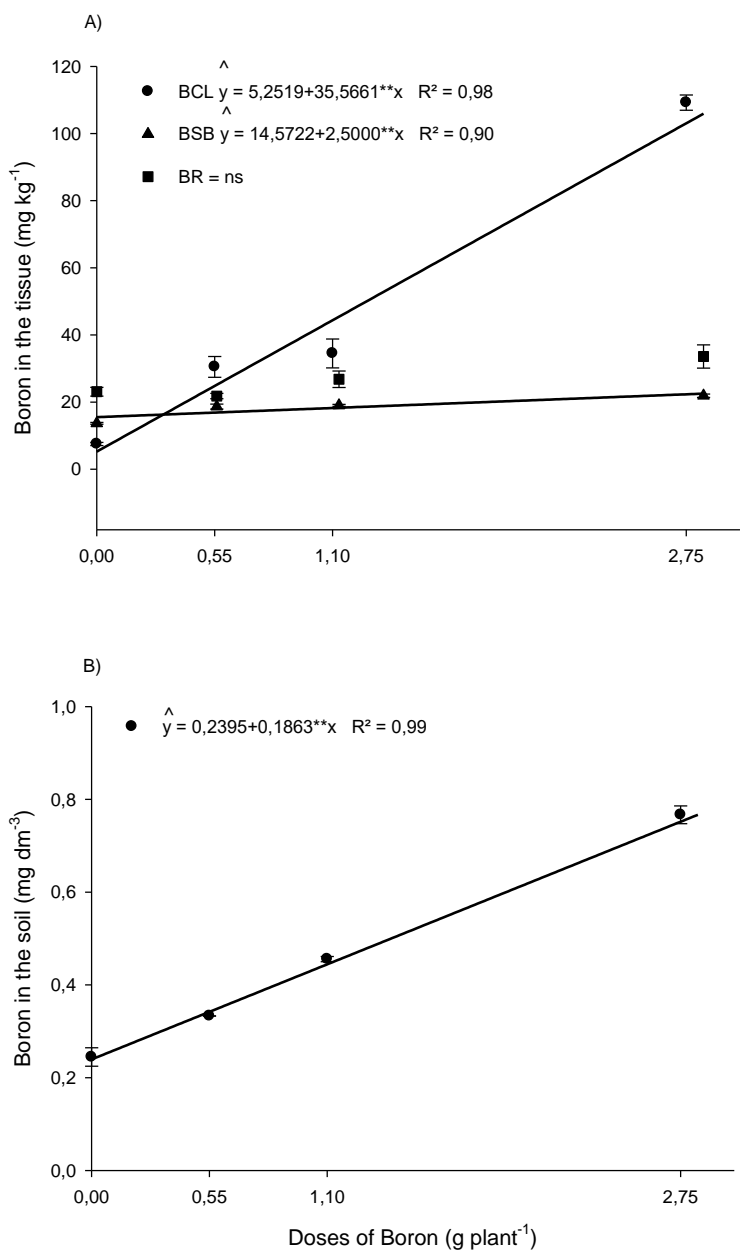

Figure 4. A) - Boron content in leaves (BCL), stem and branches (BSB) and roots (BR); B) - Boron contents in the soil of Eucalyptus benthamii submitted to boron doses and water regimes. $(* *=P$-significant value at $1 \%$ by the F-test)

\section{CONCLUSIONS}

Up to 110 days after the conduction of the experiment, Eucalyptus benthamii showed no response in production of total dry matter with the application of boron.

Visual symptoms of deficiency were observed when the nutrient was not applied, mainly with $60 \%$ of field capacity.
Even in soils with high organic matter, it is recommended to apply at least $0.55 \mathrm{~g} \mathrm{~B} \mathrm{plant}^{-1}$ to ensure adequate nutrition.

\section{REFERENCES}

CELESTRINO, T. S.; BUZETTI, S.; TEIXEIRA FILHO, M. C. M.; GAZOLA, R. N.; DINALLI, R. P.; SILVA, P. H. M.; CARVALHO A. C.; SARTO, G. D. Sources and application methods of boron in Eucalyptus crop. Londrina: Ciências Agrárias, v. 36, n. 6, p. 3579-3594, 2015.

COMISSÃO DE QUÍMICA E FERTILIDADE DO SOLO - CQFS-RS/SC. Recomendação de adubação e calagem para os estados do Rio grande do Sul e de Santa Catarina, Ed. 10. Porto Alegre: SBCS, 2004. 400p.

DELL, B.; HUANG, L. Physiological responses of plants to low boron. Plant and Soil, v. 193, p. 103-120, 1997.

\section{EMPRESA BRASILEIRA DE PESQUISA} AGROPECUÁRIA - EMBRAPA. Manual de análises quimicas de solos, plantas e fertilizantes. Brasília. Embrapa Solos, Embrapa Informática Agropecuária. Comunicação para Transferência de Tecnologia, 1999. 370p.

EMPRESA BRASILEIRA DE PESQUISA AGROPECUÁRIA - EMBRAPA. Sistema Brasileiro de Classificação de Solos. Ed. 3. Brasília: Embrapa Solos, 2013. 353p.

FERREIRA, D. F. SISVAR: a Computer Statistical Analysis System. Lavras: Ciência e Agrotecnologia, v. 35, n. 6, p. 1039-1042, 2011.

KLIPPEL, V. H.; PEZZOPANE, J. E. M.; PEZZOPANE, J. R. M.; TOLEDO, J. V. Impacto da deficiência bidrica no crescimento inicial de eucalipto. Revista Científica Eletrônica de Engenharia Florestal, v. 23, n. 1, p. 48-59, 2014.

LEITE, S. M. M.; MARINO, C. L.; BONINE, C. A. V. Resposta de clones de Eucalyptus grandis e Eucalyptus grandis $\mathrm{x}$ Eucalyptus urophilla à supressão de boro. Piracicaba, Scientia Florestalis, v.38, n. 85, p. 19-25, 2010.

MALAVOLTA, E.; KLIEMANN, H. S. Desordens nutricionais no Cerrado. Piracicaba: Potafós, 1985. 136p.

MALAVOLTA, E.; VITTI, G. C.; OLIVEIRA, A. S. Avaliação do estado nutricional das plantas: Princípios $e$ aplicações. ed. 2. Piracicaba: Potafós, 1997. 319p. 
MATIELLO E. M.; RUIZ H. A.; SILVA I. R.; GUERRA P. C.; ANDRADE V. M. Transporte de boro no solo e sua absorção por eucalipto. Revista Brasileira de Ciência do Solo, v.33, n.5, p. 821-830, 2009.

NOVAIS RF, SMYTH TJ, NUNES F. NUNES FN. Fósforo. NOVAIS RF, ALVAREZ V, VH, BARROS NF, FONTES RLF, CANTARUTI RB, NEVES JCL. eds. Fertilidade do solo. Sociedade Brasileira de Ciência do Solo. 2007; 471-550.

SCHWIDER, Y. S.; PEZZOPANE, J. E. M.; CORREA, V. B.; TOLEDO, J. V.; XAVIER, T. M. T. Efeito do déficit hidrico sobre o crescimento de eucalipto em diferentes condições microclimáticas. Goiânia. Centro Científico conhecer. Enciclopédia Biosfera, v.9, n.16, p. 888-900, 2013.

SGARBI, F.; SILVEIRA, R. L. V.A.; TAKAHASHI, E. N.; CAMARGO, M. A. F. Crescimento e produção de biomassa de clone de Eucalyptus grandis x Eucalyptus urophylla em condições de deficiência de macronutrientes, $B$ e Zn. Scientia Florestalis, v. 56, p. 69-82, 1999.

SILVEIRA, R. L. V. A.; MOREIRA, A.; TAKASHI, E. N.; SGAR, F.; BRANCO E. F. Sintomas de deficiência de macronutrientes e de boro em clones hibridos de Eucalyptus grandis com Eucalyptus urophylla. Cerne, v. 8, n.2, p.107116, 2002.

STAPE J. L.; BINKLEY, D.; RYAN, M. G.; FONSECA, S.; LOOS, R. A.; TAKAHASHI, E. N.; SILVA, C. R.; SILVA, S. R.; HAKAMADA, R. E.;
FERREIRA, J. M. A.; LIMA, A. M. N.; GAVA, J. L.; LEITE, F. P., ANDRADE H. B.; ALVES, J. M.; SILVA, G. G. C.; AZEVEDO, M. R. The Brazil eucalyptus potential productivity project: influence of water, nutrients and stand uniformity on wood production. Forest Ecology and Management, v. 259, n. 9, p. 1684-1694, 2010.

TAIZ, L.; ZEIGER, E. Fisiologia Vegetal. 5. ed. Porto Alegre: Artmed, 2013. 954p

TEDESCO, M. J.; GIANELLO, C, BISSANI, C. A; BOHNEN, H.; VOLKWEISS S.L. Análises de solo, planta e outros materiais. Ed. 2. Porto Alegre: UFRGS; 1995. 174p.

TIRLONI, C.; DANIEL O.; VITORINO A. C. T.; NOVELINO J. O.; CARDUCCI C. E.; HEID, D. M. Crescimento de Corymbia citriodora sob aplicação de boro nas épocas secas e chuvosas no Mato Grosso do Sul. Silva Lusitana, v. 19, p. 185-194, 2011.

VAIL, J. W.; CALTON, W. E.; STRANG, R. M. Dieback of Wattle: boron deficiency. Empire African Agriculture Journal, v. 23, n.2, p.100-103, 1957.

INSTITUTO BRASILEIRO DE GEOGRAFIA E ESTATÍSTICA - IBGE, 2015. Disponível em: http://www.ibge.gov.br/home/estatistica/economia/p evs/2015/default.shtm. Acesso em 18 de abril de 2017. 